\title{
Promoting Tropicana Slim Products to Cafés in Surabaya Using a Marketing Booklet
}

\author{
Clarita Ivone Rumimpunu
}

English Department, Faculty of Languages and Literature, Petra Christian University, Siwalankerto 121 131, Surabaya 60236, INDONESIA

Email: m11416004@john.petra.ac.id

\begin{abstract}
This is a Final Project report on a problem at PT. Nutrifood Indonesia. Tropicana Slim (TS) is a range of sugar free, low fat, low salt and low-calorie products. There are various ranges of TS products that can be used in Cafés, but most of the decision makers do not know that TS has other products besides sweetener. Thus, in order to introduce other products to the decision maker, a marketing tool is needed to give detail information about the products. A marketing booklet is a small book containing information about things for marketing purposes. The contents consist of general information about the company, products description, benefits of the products and contact person. To persuade the readers, Tropicana Slim's Unique Strength Points (USP) will be emphasized in the marketing booklet contents. Thus, it will help to introduce Tropicana Slim market and penetrate its various products to the Cafés.
\end{abstract}

Keywords: marketing tool, marketing booklet, USP

\section{INTRODUCTION}

\section{Background of the Company's Problem}

I was an intern at PT. Nutrifood Indonesia East Java Branch, specifically in Strategic Alliance Department of Tropicana Slim (TS) from March 2019 until May 2019.This company is located on Jl. Berbek Industri VII No.14, Jawa Timur, and engaged in distribute Food Products Suppliers. TS is one of Nutrifood Inc. trade names which provides sugar free, low fat, low salt and lowcalorie products. There are three variations of TS products: sugar free products, low-fat products and food supplement products. Sugar free products consist of sweetener, cookies, coffee, jam, syrup, cookies, etc. Low-fat products consist of various low fat or non-fat milk. Food supplement products consist of cooking oil, soy sauce and rice. The target market for those products are those people who want to maintain a healthy lifestyle (diet) and prevent diabetes.

Below I enclosed the company's structure before discussing about the department I was placed in during the internship program. 


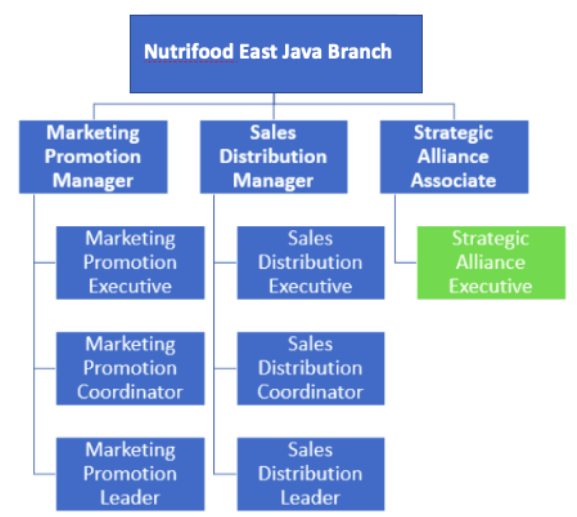

In strategic alliance department, I was placed as a Marketing Representative (MR). The aim as Marketing Representative were described into three objectives: to increase TS products availability in Hotel, Restaurant and Cafe (HORECA) channel, to restrain competitors' products availability in HORECA channel and to build strategic alliance by using all sources that Nutrifood has such as network, branding, social media, distribution channel, discount, etc.

For the first objective, there were indicators to be done. First, in a month, I had to visit 50 HORECA channel in Surabaya. Out of 50 outlets, I had to make sure that $80 \%$ of the outlets were using TS Products (especially TS Sweetener). In addition, out of $80 \%$ outlets that use TS Products, I had to make sure that $10 \%$ of the outlets were new outlets using the TS products. During the visits, I also had to do documentation by taking pictures of TS Products used in the HORECA channel as shown below.

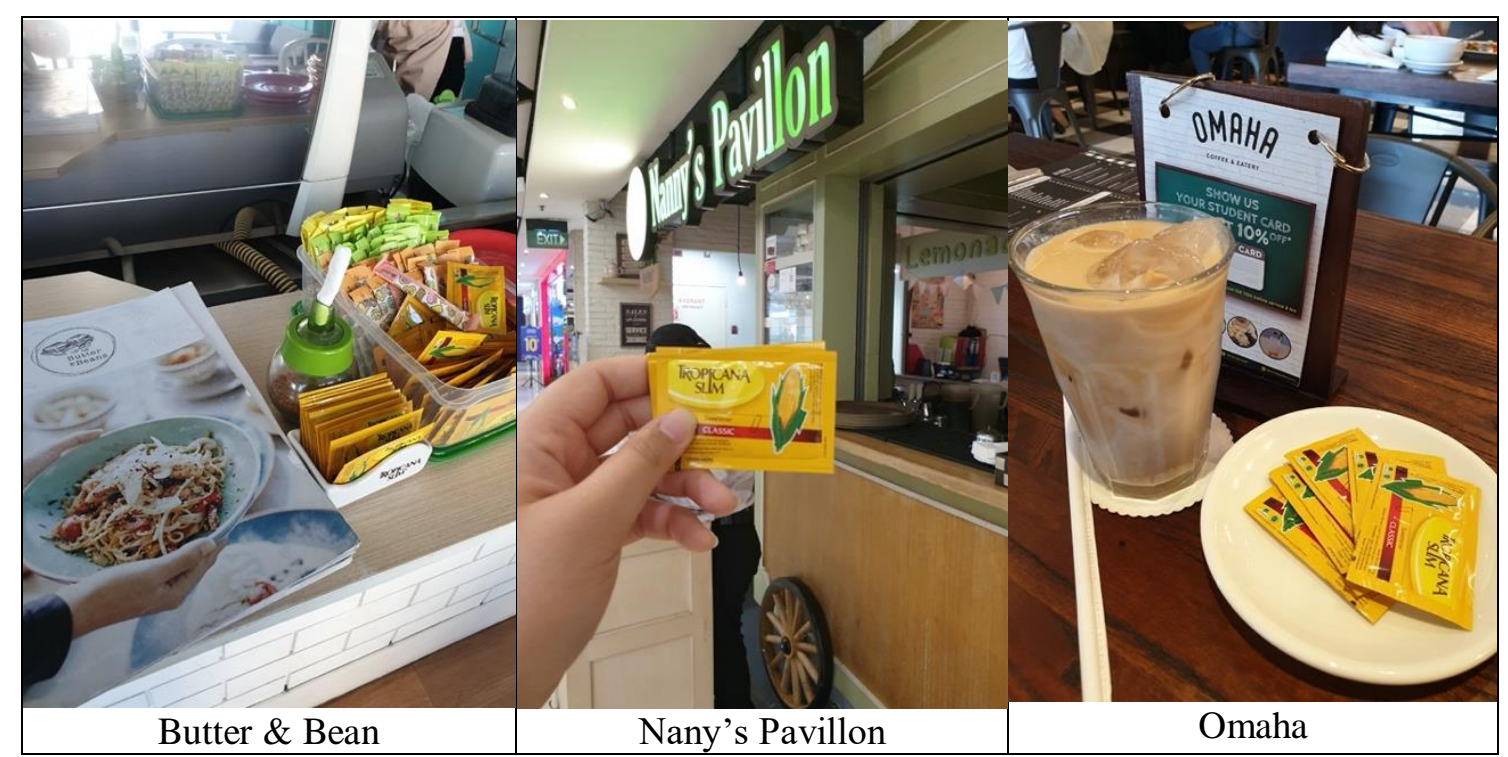

For the second objective, there were two main competitors of TS. Both competitors claim themselves as a low-calorie sweetener. Produced by the same parent company, those brands aim at the same target audience and target market as Tropicana Slim. However, there is a slight difference between those two brands and TS. One is aimed for diabetics, and the other one is aimed for people who maintain a healthy lifestyle (diet). Unlike the competitors, TS products has more variety. For example, TS Sweetener Classic that is aimed for both diabetics and diet people. Another example is TS Sweetener Diabetx that is specifically aimed for diabetics, and many more. 
If I found one of competitor brands during visits, there were several approaches that should be done. First, I should approach the decision makers (either cafes' owner or cafes' manager) and asked them whether they had used TS before. If they had used TS products, I would ask them why they changed from TS products to competitor brands and persuaded them to re-use TS products. If they had not used the TS products, I would introduce the products first, before persuading them to change from competitors.

During three months of internship program, I found out a problem when I was penetrating TS products to outlet owners. TS products have various range of products, but most decision makers were only familiar with TS Sweetener. They often asked whether TS has other products besides sweetener. At that time, I was only provided limited information about TS products and did not expect that the decision makers would want to know the other products. Even though I was just an intern back then, the decision makers perceived me as an official marketing representative from TS. I could not state that I was an intern as an excuse for not knowing other products' details. Therefore, I told the business owners that I would send the complete information about TS' product range. Next, I asked them for their contact information, so I could do a follow-up later. I stated this situation to my manager during the weekly progress report and asked for the information needed.

After searching for some information, I figured out that booklet could be a solution for this problem. I proposed this idea as my final project too, and did a further study about booklet. Based on the study, I found out that actually booklet is a well-known tool used for marketing purposes. In this project, the limitation was only for cafe owner. This limitation was defined based on the intern's experience during the internship program. First, intern was required only to visit and penetrate to restaurant and cafe channel. Hotel was not required for intern because this channel required a long term process. Second, intern often visited cafés rather than restaurants. So, intern coped well with the situation in the café channel. Third, this project wanted to produce a tool which could solve specific matter. However, the tool could still be used to inform about general information as well.

\section{Literature Review}

\section{Marketing}

Based on Cambridge Online Dictionary, marketing is described as a job that involves encouraging people to buy a product or service (Marketing, 2019). Based on its general term, marketing means an activity in order to create and exchange values with customers. A good marketing requires a deep comprehension of customers, competitors and collaborators. Thus, marketing is not only a function for specialists, but also for anyone with their career interest which need organizational strategy (Silk, 2015, p. vii). Marketing is not merely about selling and advertising. Peter Drucker argues that marketing is not specialized on an activity. It encompasses the whole business, and makes it seen from the point of view of its final result which is customer's point of view (Strydom, 2015, p.2).

\section{Marketing Mix}

Mc Carthy classified marketing mix into four actions: product, price, place and promotion (The Marketing, 2015, p.4). It can be understood as the right product, in the right place, at the right price and time. If we put it in practice, it would be:

1. Create product that particular people want

2. Sell it in the place regularly visited by the particular people

3. Market the product in the price as the particular people has expected

4. Make sure the product available when the particular people need it. 
Among those four points, promotion is the essential thing because it is the action to inform people about the product existence. Promotion is an action of communication that has a purpose to persuade others. The goal is to make the target market accept the idea or concept or thing offered to them. After they accept the idea or concept, the expected action is they will purchase the idea or concept or thing offered. This expectation can be completed through several promotional tools or marketing tools which are categorized on four groups (Materson, Phillips \& Pickton, 2017, p.294):

1. Advertising - TV, radio, press, cinema, posters, internet, etc.)

2. Public relations (PR) - sponsorship

3. Sales promotions - coupons, samples, tester

4. Personal selling - face to face presentation (perfect for Business to Business Channel) Based on this classification, marketing booklet is included in the fourth group, personal selling. The marketing booklet is a tool that is used during the face to face presentation, in order to help the marketer to inform about products or services.

\section{Marketing Tool}

Marketing tools are defined as product development and promotional strategies and actions that a company uses to develop and promote its products or services (Marketing Tools, 2019). Moreover, marketing tools are the results of an attempt to cope with constant market changing. In the marketing field, change is happening constantly (constant change) such as management changing competitive environments, changing buyer behavior, new channels of distribution, product repositioning and communication strategies, etc.

\section{Marketing Booklet}

Many people misinterpret marketing between booklet and catalogue, since the form of both tools is a book. Therefore, I review the principle about marketing booklet so that readers can have the same understanding about this project. Based on Cambridge Online Dictionary, booklet is described as a very thin book with a small number of pages and a paper cover giving information about something (Booklet, 2019). To be more specific, based on Business Dictionary, booklet is a bound publication, commonly having less than 20 pages. Unbound but fastened booklet (with or without a cover) is generally called a pamphlet (Booklet, 2019).

\section{SWOT Analysis}

The analysis technique used in this project is SWOT Analysis. SWOT is the abbreviation terms for Strength, Weakness, Opportunity and Threat analysis. This analysis technique is used to learn, start and develop a company based on SWOT factors which gained from internal (Strength and Weakness) and External (Opportunity and Threat) factors. To be more specific, each factor stands for specific needs. Strengths are those factors which give benefits for the company; weaknesses are factors that cause loss; opportunities are external factors which give benefits for the company; and last, threats are external factors that give disadvantages to the company (Materson, Phillips \& Pickton, 2017, p.77).

\section{USP Analysis}

Written by Tim Hindle on a book titled "Guides to Management Ideas and Gurus", USP is a special unique quality of a product or service which makes the product or service different rather than its rival which makes consumers choose the product or service instead of its rival (Hindle, 2008, p.233). In order to find a USP of a product or service, the first step is comparing the features of a product or service with its rivals. Next, after comparing the features, figure out 
what is/are the difference(s) between the product or service with its rival. The difference(s) is/are the USP of its product or service (Bird, 2007, p.82).

\section{METHODS}

\section{Respondents or Sources for Data Collection}

\section{Interview and Survey}

I interviewed my manager during the internship program to get information about Tropicana Slim's product. Next, in this project, I defined customer in two definitions: first, customer was the decision maker in the cafe. There were two possibilities of decision maker: cafe owner or cafe manager; they were the main target of this marketing booklet. Since this project was aimed to give general information and persuade target audience at the same time, the decision maker could provide data needed to make the marketing booklet. The interview process was done face to face by visiting them in a cafe. In order to gain data from them, I had to know how to approach them, because not all of them wanted to share information through an interview.

\section{Product Comparison}

Comparing company own products with competitors was another way to identify products USP to be used in the marketing booklet. I bought Tropicana Slim products and the competitor products, and started to compare the products. The comparison included all aspects from the product. In this project, in order to get the USPs, I compared Tropicana Slim's products' with its competitors in terms of the main ingredient, serving size, solubility, packaging and taste. The categories were based on the marketing mix classification.

\section{Online Search}

Online research were done through the company's website, the company's online store, competitors' website, and competitors' online store which provided the data needed. In addition, the acceptable online platform for the data collection excluded personal blog in order to hinder subjective information.

\section{Steps to Get the USP}

The USP was found out through SWOT Analysis. As explained in the second chapter, SWOT is the analysis technique used to develop a company. First, the data collected were categorized into SWOT categories. Before putting the data into four categories, the data should have been classified into two main groups: internal and external. After dividing it into two main groups, I classified the data from the internal group into Strengths and Weaknesses. Next, I classified the data from the external group into Opportunities and Threats.

After identifying these two groups, I had completed the SWOT Analysis. The strengths that only TS products had were the USP of TS products. These data would be emphasized in the marketing booklet content. The opportunities were factors considered when designing the marketing booklet. The aim was to grasp the opportunities using the marketing booklet. The weaknesses were factors that must be handled in order to maintain the reputation. Lastly, the threats were factors that must be prevented and considered when designing the marketing booklet.

\section{FINDINGS \& DISCUSSION}

There were six decision makers of cafés in Surabaya that became my interviewees. Based on the in-depth interview with the decision makers, I managed to figure out the usage of Tropicana Slim 
in cafés. Among various Tropicana Slim product range, the most-used product by cafés is Sweetener Classic. The sweetener was placed in a sugar bowl and was given to café customers based on their request. However, there were some cafés which provided the sweetener along with the beverages, even though the customers did not ask for it.

Based on the interviewee's answers, their customers did not bother about the sweetener variation. As long as its brand is Tropicana Slim, cafés customers would accept it. In addition, Sweetener Classic was also known as Tropicana Slim "basic" sweetener, because it did not have a specific function unlike the other Tropicana Slim sweeteners. For example, Sweetener Diabtx was made specifically for diabetics. The function of the product was not to prevent diabetes, but to control diabetics' blood sugar so that it would stay stable. Thus, the function of Sweetener Classic was the underlying reason why café decision makers chose Sweetener Classic rather than other variations.

Next, Tropicana Slim usage depends on the demand of café's customers. Each café might have different results which was affected by many factors. The usage of sweetener in a cafe might vary with an average of $80 \sim 200$ sachets each month. If we wanted to break down the usage details, the average usage in one day was two to five sachets. Usually, café would provide two until three sweeteners for each person. However in practice, there are some customers who asked for five until six sweeteners, even though it exceeded the serving size.

The interviewees bought Tropicana Slim either from distributor or retail. The number of usage in each café determined from who the product would be bought. If the number of usage was around $80 \sim 100$ or under that number, they usually bought it from retailer. On the other hand, if the number of usage was around 100 200 or above, they usually contacted the distributor.

According to the six interviewees most of the time, the customers who asked for sweetener were middle-aged adults (35-55 years old) and older adults (above 55 years old). Thus, it created an idea that sweetener was used only for old people. Moreover, because of its benefits (low-calorie, sugar-free, low-fat and low-salt), sweetener was frequently associated with diabetes. In consequence, it gave an idea that only diabetics who needed sweetener. The value of sweetener, what the customer perceived, was misleading since it could be used to prevent diabetics and maintain a healthy lifestyle.

Additionally, the six interviewees stated that they did not have any intention to switch Tropicana Slim into other brands. There were two reasons for this decision. First, the decision makers used Tropicana Slim because of their customers request. Two out of six interviewees said that their customers only wanted Tropicana Slim for their sweetener. They would reject if they were given other brands besides Tropicana Slim. For their customers, Tropicana Slim was a trusted sweetener brand.

Second, three out of six interviewees stated that their café's parent company had collaborated with Nutrifood Indonesia. Thus, in every branch of their cafés, they would display and serve Tropicana Slim for their customers. Lastly, one out of six interviewees stated that s/he used Tropicana Slim for its good taste; its taste was similar to sugar. They had tried the other brands, and for them the taste was not good; it left a bitter taste, unlike Tropicana Slim. As a consequence, cafe's decision maker preferred Tropicana Slim over other brands.

\section{Customer Survey (with café's customers)}

Based on this survey, the data collected was Tropicana Slim market segmentation and their point of view regarding the product. In this survey, there were 101 respondents participating to fill the survey. Out of 101 respondents, 42 respondents chose Tropicana Slim as their selection. Answers 
from these 42 respondents were examined in order to gain data for SWOT analysis. All respondents were domiciled in Surabaya, especially in East, West, South and Central Surabaya.

The survey was divided into two sections: market segmentation and end user point of view. In market segmentation section, the questions were designed in order to figure out customer's demographic and lifestyle based on controlled geography. Thus, customer's demographic and lifestyle could give an idea about Tropicana Slim's customers characteristic. In audience point of view section, the respondents answered open-ended questions about their reasons for choosing Tropicana Slim as their sweetener's brand. These reasons were classified into strengths or opportunities group in SWOT analysis. Below were the results:

\section{Customer's Demographic}

Demographic was identified through three factors: age, gender and income. As shown in the first chart below, Tropicana Slim's customers were mostly middle-aged adults, followed by young adults and teens.

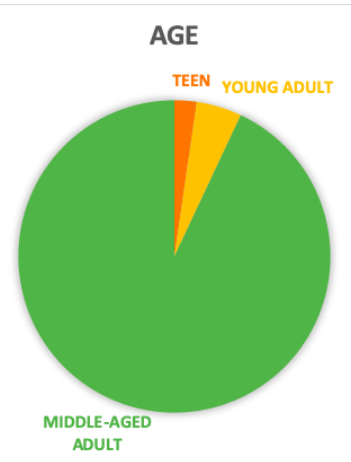

Young-adults were people who age around 18-35 years old (there were several versions about this classification). People in this group were in their most productive time. They should have visited many places to work, study, look for entertainment, etc. Thus, in this project, I considered the preference of this group, especially their preferences about café.

One of their preferences was following the trend. As a consequence, I could use the information to persuade cafés' decision makers, by giving the latest trend was healthy lifestyle among youngadult. Tropicana Slim was a range of healthy products that could support the healthy lifestyle, so it would be good if cafés serve it to fill the demand.

Next, Tropicana Slim customers based on this survey were mostly women rather than men, as displayed in the chart below.

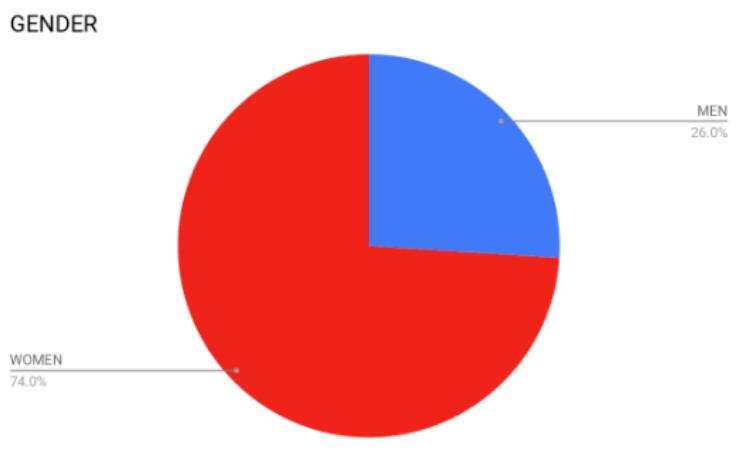

Women trait tended to pay attention about their appearance. Thus, in this project, I would emphasize the fact Tropicana Slim could help people to maintain a healthy lifestyle or diet. As a 
result, this could also target cafés that often visited by socialites, who would pay attention to their sugar intake. By emphasizing this fact, it would build an idea for cafés decision makers to provide Tropicana Slim products to fill the potential demand.

Lastly, from this survey, the income of most respondents was in range Rp 1,000,000 5,000,000 as seen in the chart below.

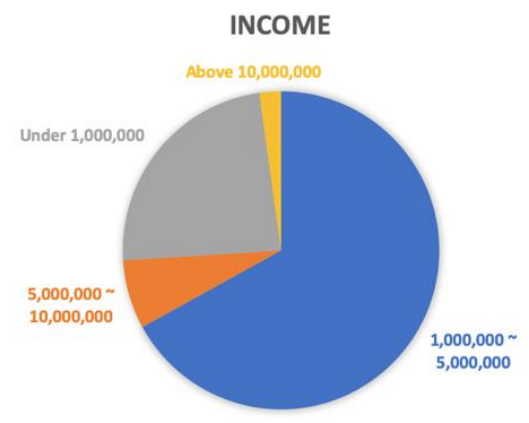

Therefore, it could be concluded that Tropicana Slim target audience was middle class group, and possibly upper-class group as well. Middle-class group to upper-class group tended to pay more attention to the quality of products they would consume, since they had bigger buying power rather than lower-class group. This fact made them not hesitate to buy expensive products as long as the quality was good. So, in the marketing booklet, I emphasized the fact that Tropicana Slim was a high quality product that suited the best to be served for café's customers.

\section{Customer's Point of View}

In this section, respondents were asked about the reasons for Tropicana Slim instead of choosing other sweetener brands. The data then would be the strengths of Tropicana Slim products that were confirmed by customers. As the result, the reasons for choosing Tropicana Slim were displayed in the chart below:

Respondents mentioned six main reasons for choosing Tropicana Slim as their sweetener brands: product fame, claiming as loyal customers, product's accessibility, recommended by their family, product range and product's taste.

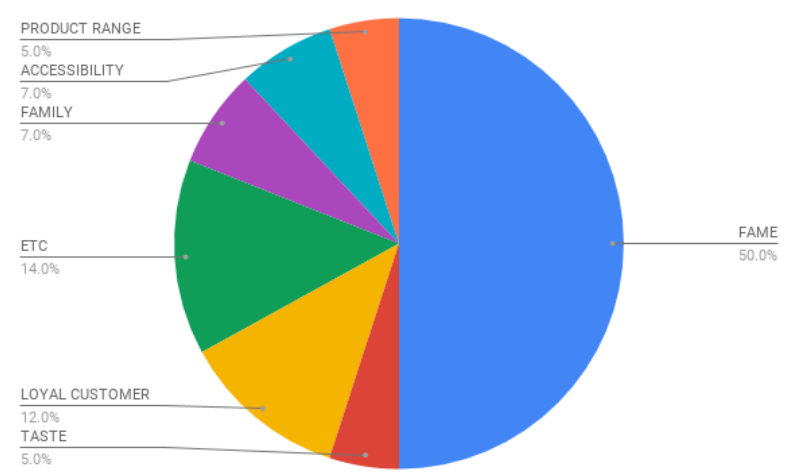

The majority of respondents chose Tropicana Slim for its fame. Following this reason was respondents who claimed themselves as Tropicana Slim's loyal customers. Next, with the same percentage, reasons for choosing Tropicana Slim were product's accessibility and recommended by respondents' family. There were two reasons for choosing this product: product's taste and product range. From this chart, I could conclude that Tropicana Slim's brand awareness was good and became the strength of this product. Thus, in this project, I would include the fact about this product's good brand awareness. 


\section{Product Comparison}

In this section I compared Tropicana Slim with its competitors. I compared TS products with the competitors in terms of product's main ingredient, serving size, solubility, packaging and taste. The comparison was displayed in the table below:

\begin{tabular}{|c|c|c|c|}
\hline Products Distinction & Tropicana Slim & $\mathrm{X}$ & $\mathrm{Y}$ \\
\hline Product's Main Ingredient & Sorbitol & Lactose & Maltodextrin \\
\hline Serving Size & $@ 2,5 \mathrm{gr} / \mathrm{sachet}$ & @ $1,5 \mathrm{gr} / \mathrm{sach}$ t & @ $1,5 \mathrm{gr} / \mathrm{sachet}$ \\
\hline Product's solubility & $\begin{array}{c}\text { Soluble } \\
\text { (without stirring) }\end{array}$ & Soluble & Clump \\
\hline Product's packaging & Sachet & Sachet & Sachet \\
\hline Product's taste & Close to sugar & Close to sugar & A little bit bitter \\
\hline
\end{tabular}

Based on the products comparison, I found out that only Tropicana Slim used natural ingredient (sorbitol). In addition, compared to the competitors, Tropicana Slim's serving size was larger than the other brands. As a consequence, from this comparison, I could conclude that one of Tropicana Slim's strengths was using natural ingredients unlike the other brands.

\section{Result of SWOT Analysis based on Customer Interview and Survey}

The data collected from the respondents and sources were classified into two groups: Internal and External group. Internal group consists of strengths and weaknesses of Tropicana Slim products. External group consists of opportunities and threats of Tropicana Slim products. Those data, which were classified into four sub-categories, were presented in the table below:

\begin{tabular}{|c|c|c|c|}
\hline STRENGTHS & WEAKNESSES & OPPORTUNITIES & THREATS \\
\hline $\begin{array}{l}\text { TS has a good } \\
\text { brand awareness } \\
\text { compared to } \\
\text { competitors. } \\
\text { TS has various } \\
\text { product range. } \\
\text { TS is considered as } \\
\text { high quality } \\
\text { product. } \\
\text { TS is the only } \\
\text { sweetener brand } \\
\text { which uses natural } \\
\text { ingredients. }\end{array}$ & $\begin{array}{l}\text { Tropicana Slim's } \\
\text { latest products are not } \\
\text { as famous as its } \\
\text { signature product } \\
\text { Tropicana Slim price } \\
\text { is more expensive than } \\
\text { the competitors. }\end{array}$ & $\begin{array}{l}\text { Healthy lifestyle is } \\
\text { becoming people's } \\
\text { concern nowadays. } \\
\text { There are new markets } \\
\text { that require health } \\
\text { products (gym, hospital, } \\
\text { HORECA) }\end{array}$ & $\begin{array}{l}\text { People think that } \\
\text { Tropicana Slim is only } \\
\text { consumed by diabetics } \\
\text { which leads to a stigma } \\
\text { that Tropicana Slim is used } \\
\text { by older adults only } \\
\text { (usually suffer from } \\
\text { diabetes) } \\
\text { The competitors are } \\
\text { targeting the same target } \\
\text { market. }\end{array}$ \\
\hline
\end{tabular}




\section{Result of USP}

Based on the SWOT analysis, there were four USPs that were found in Tropicana Slim products as listed below:

1. Tropicana Slim has various product range compared to other sweetener brands.

a. Tropicana Slim has other good products beside sweetener, such as honey, sweetened condensed milk, cookies, jam, syrup, coffee, etc.

2. Tropicana Slim uses natural and healthy ingredients, unlike its competitor.

a. The ingredients are safe for dieters and diabetics based on the recommended serving size.

3. Tropicana Slim is a high quality product.

a. This statement is supported by the fact that: it has natural taste like sugar, it does not taste bitter, it has the most delicate and soluble powder, and it leaves no aftertaste.

4. Tropicana Slim has a good brand image compared to other sweetener brands.

a. Our products have gained trust among sweetener users for its good track record since 1976.

Marketing Booklet Content and Its Explanation (content, organization, parts, order, language)

In this section, I explained how the strengths were implemented in the marketing booklet's contents.

1. COVER

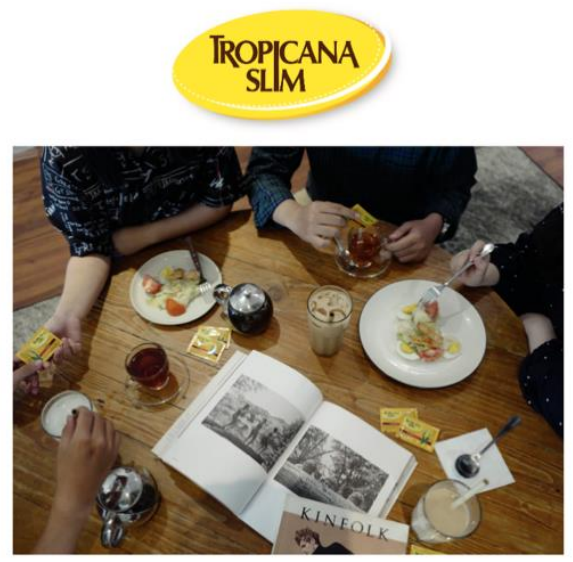

In the cover, I used the picture of people enjoying their foods and beverages using Tropicana Slim. The picture focused on the existence of Tropicana Slim products used by people with their foods and beverafes. The image selection was based on the café characteristic, so that when the readers (café decision makers) see the image, they could get an idea that Tropicana Slim products were relevant with their business. As mentioned in Chapter 2, there were considerations to choose the image style. In this project, I did not choose illustration as the supported image because it did not display the ambience of a café optimally. By using a photo as supported image, the ambience of a café can be shown clearly as if it is the real situation. It also gave an idea about how Tropicana Slim as product companion for café beverages.

\section{TABLE OF CONTENTS}

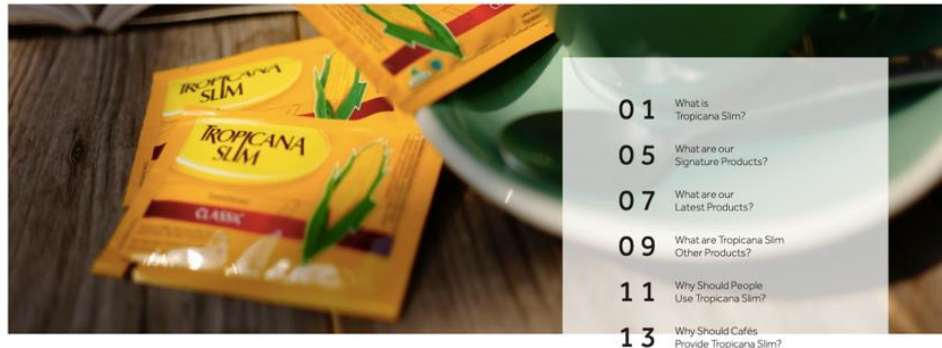

CONTENTS.
In the table of contents, I used interrogative sentences because it would persuade the readers to figure out the answers. Interrogative sentences were used to ask a direct question which requires an answer. Thus when the readers read, the expectation was to make the readers want to know further about the information. This 
section showed the implementation of word choices. The marketing booklet did not only pay attention about the diction, but also the format sentence used in the tools. The aim of this tool was to inform and persuade. Using correct format sentence would make the marketing booklet achieve its goals.

\section{WHAT IS TROPICANA SLIM?}

o1

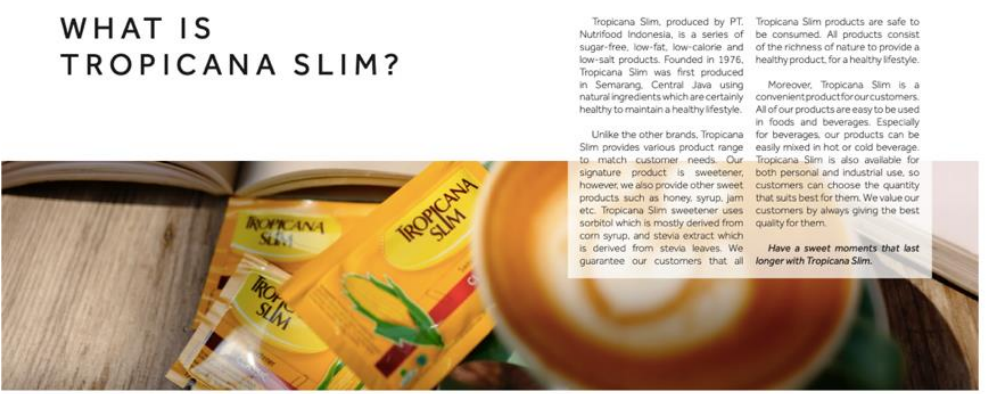

o2 In this section, there were three paragraphs and Tropicana Slim's tagline. The first paragraph gave general information about what Tropicana Slim was. The second and third paragraph gave information regarding Tropicana Slim's USPs generally. Last, the tagline was given as a call to action for the readers.

4. WHAT ARE OUR SIGNATURE PRODUCTS? \& WHAT ARE OUR LATEST PRODUCTS?

The signature products were explained in a paragraph and supported by the image as the

WHAT ARE OUR

SIGNATURE

PRODUCTS ?

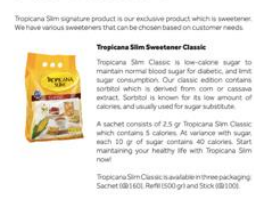

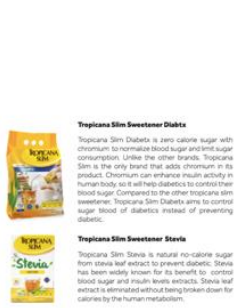
"
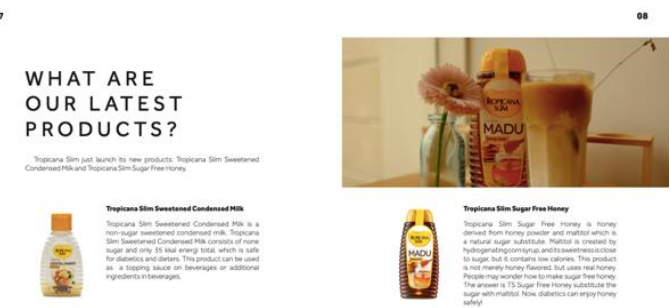

visualization. In each paragraph, it was opened with a topic sentence, and then followed by several supports. This concept was chosen in order to convince readers. It would make the topic sentence was credible and reliable by giving support to the topic sentences.

\section{WHAT ARE TROPICANA SLIM'S OTHER PRODUCTS?}

$\circ$

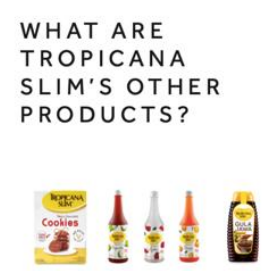

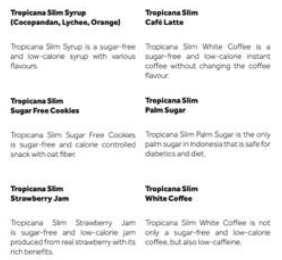

10 The other products of Tropicana Slim were not explained in detail unlike the signature product and latest product, because the highlight in this project was the signature product and latest product. Thus, the other products were explained only in a sentence, without any further elaboration. In this case, layouting was important so that the readers would not be confused when they read about the information. Compared to page six, each products had its own description and picture. It could not be applied in this section because there would not be enough space to put the picture. With the same reason, compared to page eight which displayed a big picture and products' picture as the supporting image, this page only showed picture of the products because this page explained more products than the other sections. If this section wanted to use the same concept as section page eight, it would lessen the amount of white space - unsightly. 
6. WHY SHOULD PEOPLE USE TROPICANA SLIM? \& WHY SHOULD CAFÉS PROVIDE TROPICANA SLIM?

In this section, the purpose was to convince readers about reasons to use this product instead of
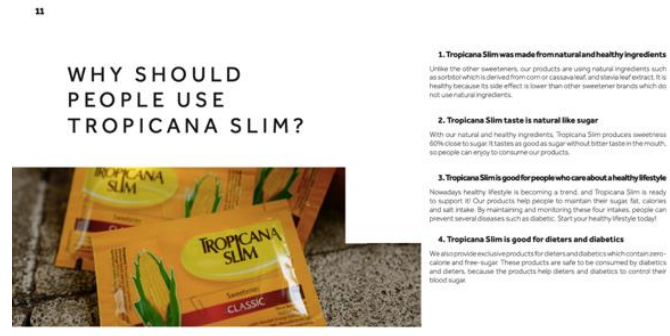

WHY SHOULD TROPICANA SLIM?

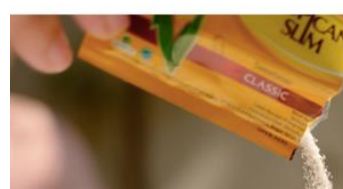

the other products. The organization of this section was using numbers, with each topic sentence bolded. Unlike the section about signature product and latest product, the topic sentence in this section was bolded because this section wanted to persuade readers. Just like the signature product and latest product section, this section also used topic sentence and supports. As mentioned in chapter two, font selection was important because it helped convey the information clearly. The sentences bolded were used to attract people to read that first. People were tended to read bolded sentences because those attract their attention. There were considerations in choosing sentences that want to be bolded. In this section, all topic sentences were bolded because topic sentences sum up the main idea in a sentence. It gave brief and direct information to the readers. By bolding the topic sentence, it emphasized the topic sentence and attract readers attention, then they would read it and the important information would be delivered.

\section{CONTACT PERSON}

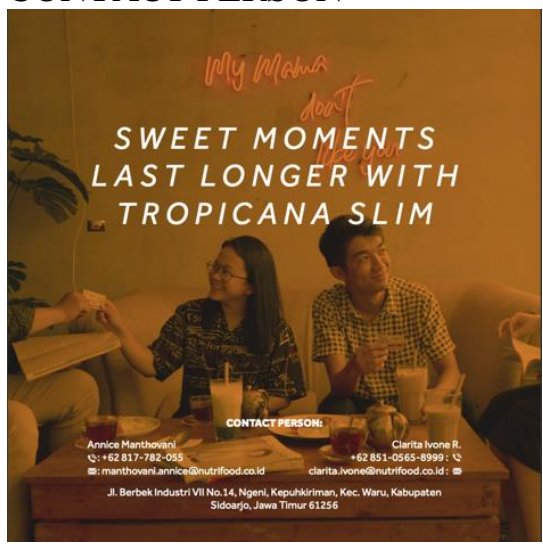

Last, in the contact person section, I provided two contact person to give alternative if one of them could not be reached out. I also gave the address of East Java branch if the readers wanted to send business proposal or visit the company directly. Above the contact person's information, there is Tropicana Slim's tagline to persuade readers and increase the brand awareness.

\section{CONCLUSION}

In the marketing booklet, the contents consist of general information about the company, products description, benefits of the product and contact person. The USP found were implemented in the content, especially in products description and benefits. By using this marketing booklet, there were benefits for the company: it gave a good impression to the decision makers, because TS considered their preference (to know about Tropicana Slim's other products) as an important note, and it could increase the possibility for Tropicana Slim's other products to penetrate HORECA Channel, especially cafés. For the next project, I suggest for making a set of marketing tool instead of only one marketing tool. In my case, the output of my final project was marketing booklet. As I mentioned before, this marketing booklet contained general information along with specific information used to persuade the readers. There are other marketing tools which main purpose is specifically only to persuade the readers. It would be better that in the future Final Project, the output will be a kit or a set of marketing tools in order to solve the company problem. 


\section{REFERENCES}

Bird, D. (2007). Commonsense direct \& digital marketing (5th ed., p. 82). London; England: Kogan Page.

Booklet. (2019). Business Dictionary. Retrieved from http://www.businessdictionary.com /definition/booklet.html

Booklet. (2019). Cambridge Dictionary Online. Retrieved from https://dictionary.cambridge.org /dictionary/english/booklet

Hindle, T. (2008). Guide to management ideas and gurus (p. 197). London, England: Profile Books.

Marketing Tools. (2019). Your Dictionary. Retrieved from https://www.yourdictionary.com /marketing-tools

Marketing. (2019). Cambridge Dictionary Online. Retrieved from https://dictionary.cambridge.org/dictionary/english/marketing

Masterson, R., Phillips, N., \& Pickton, D. (2017). Marketing: an introduction (2nd ed.). Los Angeles: SAGE.

Silk, A. J. (2015). What is marketing? Boston: Harvard Business Review Press.

Strydom, J. (2015). Introduction to marketing. Cape Town, South Africa: Juta.

The Marketing mix: master the 4 Ps of Marketing. (2015). Namur: Lemaitre Publishing. 